\title{
A Dynamic Study on Housing and Stock Market in Europe : Focused on Greece*
}

\author{
Dong-Bin JEONG \\ Professor, Department of Information Statistics, Gangneung-Wonju National University, Korea. \\ E-mail: dj@gwnu.ac.kr
}

Received: February 4, 2020. Revised: February 26, 2020. Accepted: February 29, 2020.

\begin{abstract}
Purpose - This study examines what are the asset market fluctuations in Europe and how each economic variable affects major variables, and explore the dynamics of housing and stock market through Greece. The variables under consideration are balance on current account (BCA), index of stock (STOCK), gross domestic product (GDP), housing price indices (HOUSING), M3, real rate of interest (IR_REAL) and household credits (LOAN). We investigate the functional and causal relationships between housing and stock market.

Research design, data, and methodology - Vector error correction model (VECM) is used to figure out the dynamic relationships among variables. This study also contains the augmented Dickey-Fuller unit root, cointegration, Granger causality test, and impulse response function and variance decomposition analysis by EViews 11.0.

Results - The statistical tests show that all variables under consideration have one unit root and there is a longterm equilibrium relationship among variables for Greece. GDP, IR_REAL, M3, STOCK and LOAN can be considered as causal factors to affect real estate market, while GDP, LOAN, M3, BCA and HOUSING can bring direct effects to stock market in Greece.
\end{abstract}

Conclusions - It can be judged that the policy that affects the lending policy of financial institutions may be more effective than the indirect variable such as monetary interest rate.

Keywords: Cointegration, Unit root test, Vector Error Correction model

JEL Classification Code: C01, M22.

\footnotetext{
* This work was supported by the Research Institute of Natural Science of Gangneung-Wonju National University
} 


\section{Introduction}

As mortgage rates fall to the bottom, the housing market in major European cities is booming and 20-year mortgage rates in major European cities are below 1\% per year. Euro-zone residents make up 25 percent of their salary to pay their rent or pay their mortgage, which jumped significantly compared to the previous $(17 \%)$.

The real estate market overheating and price hikes due to low interest rates are also prominent in Europe. In some cities, where housing prices have risen so steeply that ordinary people cannot afford it, they have come up with super-hard measures, such as measures to freeze rent. In major European cities, the market's money is concentrated in the real estate market due to ultra-low interest rates, such as the 20 -year mortgage rate of less than $1 \%$.

In the past five years, the European Central Bank's negative interest rate policy has pushed property prices up at least 30\% in Frankfurt, Amsterdam, the Netherlands, Stockholm and Madrid, Spain. In Portugal, Luxembourg, Slovakia and Ireland, the average has risen more than $40 \%$.

There are signs of overvaluation in the rise of real estate prices in many Euro member states, the number of individuals who owe money to buy a home is increasing, and the economic impact of the real estate market could be dangerous. If the price of a property plummets, it warns that the aftermath will not only affect the property but also affect banks and other investors. Unreasonable real estate investment is fueled by low interest rates, according to The European System Risk Commission. Greece had a high economic growth of around $4 \%$ per year, surpassing the Euro-zone average from 1998 to 2007, with financial investments from other euro countries before and after joining the Euro-zone in 2001.

After the 2008 financial crisis in the United States, investors in the Euro-zone began to recover a significant amount of investment from Greece, devastating Greek private banking and real estate. This, combined with various internal factors, led to a worsening of current account and fiscal deficits, resulting in a sharp economic crisis.

Greece has a very weak tax base due to the poor financial system, corruption and tax evasion by taxpayers such that underground economy accounts for about $25 \%$ of GDP. In Greece, the service sector, including the public sector, accounts for about $90 \%$ of GDP, and the manufacturing sector is weakly based on imports. Greece's industrial structure, which depends on tourism and shipping and is vulnerable to economic fluctuations, exacerbates the problem of fiscal deficits.

Greece has cut its wages and pensions to relieve its fiscal deficit, due to the use of the euro, without its own monetary policy, and major restructuring aimed to increase domestic production and export competitiveness. As a result, however, the economy has suffered severe economic downturns such as falling economic growth and rising unemployment.

Meanwhile, real estate prices in Greece fell $42.7 \%$ from 2008 to 2017. In the first eight months of 2018, the number of residential real estate transfers recorded in Athens land registrations increased $59.6 \%$ year-on-year, and property and lease taxes also increased. The Greek economy grew about $2 \%$ in 2018 , the highest growth rate since 2007.

In this work, economic variables that were mentioned as the cause of the bubble of the asset market in the countries that have occurred since 1990 can be identified, so that we may respond to the non-rational bubble of the asset market through stable observation and management of the variables.

Furthermore, by analyzing the process of spreading the crisis after the bubble collapse, we will find out how the asset market and the international asset market interacted in the country and use it to prevent future crisis. To this end, we analyze the overheating European stock and real estate markets to identify the order and the central factors that have been influenced and influenced by asset markets.

This study identifies major economic variables that caused the asset market bubble in Europe recently, and empirical analysis can investigate the dynamic connections among them. Section 2 examines the theoretical discussions and previous studies that have been conducted, and section 3 presents the empirical results of this paper. Finally, section 4 discusses conclusions, the limitations of papers, and future paper directions.

\section{Literature Review}

The Euro-zone crisis has developed rapidly from the financial crisis to the fiscal crisis. Contrary to popular understanding, the European fiscal crisis, centered on GIIPS countries, is fundamentally attributable to the structural deficiencies of the Euro-zone, not their lax financial management. In particular, the lack of integrated financial oversight, which corresponds to the launch of the capital market and the euro, that is, the lack of financial integration, is the root cause of the current crisis. If unregulated rapid expansion of private credit has weakened the 
economic structure of GIIPS countries, the rapid credit outflow from the global financial crisis has caused a serious fiscal crisis.

Schularick and Taylor (2012) analyzed the conditional fixed effect logit model with the credit loan variable and stock price variable as explanatory variables for 14 developed countries that had financial crisis from 1870 to 2012 and it was found that the effect of domestic total credit loan on the financial crisis was greater than that of the currency (M2) after World War II and monetary policy reaction of financial crises made also further triggered.

Gourinchas and Obsfeld (2012) analyzed the impact of credit boom on economic crisis by focusing on 'credit boom', an important determinant of financial crisis. Here, they defined the credit boom as "when the value of deviating from the long-term trend of credit to GDP is positive" The results of this study showed that developed countries had the effect of financial crisis one to two years after the credit boom, and developing countries had the financial crisis one year after the credit boom and one to three years after the credit boom.

Reinhart and Rogoff (2009) pointed out that if an economy is in a bubble, it is very difficult to detect this bubble, and the asset price is likely to fall into a syndrome that will rise forever. In addition, they concluded that the global financial crisis makes it difficult for many countries to find a breakthrough through export promotion or to make consumption easier through foreign borrowing and that the default of emerging market economies is on a steep rise, once many countries are facing the domestic banking crisis at the same time.

Financial integration is important because it is an accurate prescription for the current crisis and extends European integration to the banking and financial sectors. Attempts to further strengthen fiscal discipline through the bailout are not only a fundamental solution to the current financial crisis, but also pose a danger of deepening the polarization problem and political conflict surrounding it. This conflict will be a key factor in determining the future of European integration (Bae, 2016).

Park and Yi (2014) empirically analyze the VAR model and VECM to investigate the monetary and fiscal policy effects of nine EU member states, using the quarterly data from 1980 to 2012. As a result, monetary policy has a greater impact on national gross domestic product and Sweden and the impact of monetary policy is consistent in Austria, Greece, Portugal, Spain. In Denmark, Ireland and the Netherlands, fiscal policy has a greater impact on the gross national product of these countries, but the response of GDP to the impact of Danish government spending is not significant. In Ireland, the effect is short-term, whereas in the Netherlands, the effects of fiscal policy continue to be affected. In Italy, neither monetary nor monetary policy had a significant impact on GDP. In Austria, Greece, Portugal, Spain, and Sweden, this means that monetary growth will have a positive impact on economic growth. On the other hand, in Denmark, Ireland and the Netherlands, the increase in government spending has a positive effect on economic growth.

The Greek debt crisis is the result of the Greek government's delay in reform and extreme inefficiency, but it is not independent of the structural imbalances and structural contradictions of the Euro-zone. The overall truth of the Greek debt drama can be clarified by considering the structural background of the euro crisis and the changes in the EU's response to the crisis. In the background of the euro crisis, there are three structural aspects that act in combination: European Union's financial market integration, the Euro-zone's structural imbalances, and the institutional deficits of transnational nationality.

Koo (2015) analyzes the EU's response to the euro crisis in two stages. In the first stage of the crisis, emergency relief and stimulus policies for banks were made at the individual member level, and financial regulation was discussed at the EU level. However, in the second stage of the crisis since 2010, the financial crisis calls the fiscal crisis, and the EU's response is aimed at stabilizing the euro zone, consolidating tightening policy, reforming the structure and strengthening competitiveness.

\section{Empirical Study}

The empirical analysis introduces the data of Greece to be analyzed and performs unit root test, Johansen cointegration test, Granger causality test, and vector error correction model fit, and both impulse response function and variance decomposition are used to analyze the influence of the variables. Of course, in order to apply the vector error correction model, the tests must be carried out together with the cointegration constraint.

\subsection{Data Collection}

For the data to be analyzed, quarterly data from Q1 1997 to Q4 2018 were used. Each of the seven variables considered is the current account balance (BCA), real interest rate (IR_REAL), gross domestic product (GDP), 
housing price index (HOUSING), stock index (STOCK), household loan (LOAN), and currency volume (M3). Time series data considered in this paper were extracted from both Eurostat and Federal Reserve Bank of ST. Louis.

In this study, we consider current account data as capital surplus data and consider it as an inflow effect of foreign capital that has influenced price increase in asset market. Not that the stock index based on January 2010 at 100 in OECD is used in common by comparing it by country.

Here, 'M3' is an indicator developed for the purpose of understanding the liquidity level of all financial institutions including not only banks but also non-bank financial institutions. The real interest rate is the interest rate deducting inflation (GDP deflator) from the nominal lending rate, and the current account balance is the current account balance that covers the costable foreign trade balance.

The logarithmic transformation was performed on five variables except current account and real interest rate. In addition, EViews 11.0 was used for the empirical analysis. While Gross domestic product, home price index, household loans, and money supply continued to increase from the beginning to 2007 and then declined, current account balance shifted from decreasing to an inflection point (expanding the current account deficit) in 2007 and increasing (currently the current account deficit improvement trend), while maintaining large fluctuations every year.

Real interest rates remained low from the beginning of 2001 to the first half of 2008, after which they rose sharply and remained constant, and the stock index surged in 1998 and 2000, adjusted, and peaked in 4Q 2007, and has since plummeted since $2^{\text {nd }}$ half of 2008 .

Nearly all variables can be assumed to be nonstationary time series data. This non-stationarity has been incorporated into the Euro-zone since 2001, and the economy has undergone major changes, and this is because the economic index is implicated by the 2008 Lehman crisis and the 2008 Greek financial crisis.

\subsection{Unit root test}

In order to test the stationarity of time series data, this study uses the following three types of augmented DickeyFuller (ADF) test so that we can test the existence of unit roots. The five variables except current account and real interest rate were log-converted to the original data and then unit root test was performed (Dickey \& Fuller, 1979; Said \& Dickey, 1984).

$$
\begin{aligned}
& \Delta X_{t}=\delta X_{t-1}+\sum_{i=1}^{p} \beta_{i} \Delta X_{t-i}+u_{t} \\
& \Delta X_{t}=\alpha+\delta X_{t-1}+\sum_{i=1}^{p} \beta_{i} \Delta X_{t-i}+u_{t} \\
& \Delta X_{t}=\alpha+\gamma T+\delta X_{t-1}+\sum_{i=1}^{p} \beta_{i} \Delta X_{t-i}+u_{t}
\end{aligned}
$$

The null hypothesis given below shows that each seven variables in Greece has unit roots, and when the p-value is less than the significance level $5 \%$, the null hypothesis is rejected and no unit roots can be interpreted.

Table 1: Unit root test

\begin{tabular}{|c|c|c|c|c|}
\hline \multirow{2}{*}{ Variable } & \multicolumn{2}{|c|}{ Original series } & \multicolumn{2}{c|}{$1^{\text {st }}$ differenced series $(\mathrm{I}(1))$} \\
\cline { 2 - 5 } & ADF & P-value & ADF & P-value \\
\hline BCA & -.635875 & .9738 & -23.73673 & $<.0001^{* *}$ \\
\hline IR_REAL & -1.065993 & .2567 & -11.01395 & $<.0001^{* *}$ \\
\hline GDP & -.986744 & .9395 & -7.400588 & $<.0001^{* *}$ \\
\hline HOUSING & -.946605 & .9448 & -9.765254 & $<.0001^{* *}$ \\
\hline LOAN & -2.809219 & .1987 & -3.640744 & $.0071^{* *}$ \\
\hline M3 & -2.209858 & .2045 & -5.935147 & $<.0001^{* *}$ \\
\hline STOCK & -2.411084 & .3711 & -6.117805 & $<.0001^{* *}$ \\
\hline
\end{tabular}

**highly significant, * significant

All of the time series variables considered became a stationary time series after the first order difference, which is considered to be the first integral, I(1) (see Table 1). 


\subsection{Johansen's cointegration test}

As we saw in the unit root test results in section 3.2, all seven variables in Greece are I(1), so we need to check whether there is a long-term equilibrium relationship between the nonstationary time series by conducting a cointegration test.

Before the Johansen cointegration test, the test results are sensitively affected by the length of the time difference (p). Therefore, the vector autoregressive models of various time difference are estimated to choose the optimal time difference using the AIC and SC criteria (Engel \& Granger, 1987; Cho, 2006; Granger, 2004).

After the vector autoregressive model was fitted for each variable, the test can be used by optimal lag ' 2 ' using 2 because the calculated SC presents the lag '2'. Based on EViews 11.0 conintegration test specification, model 2(Assume no deterministic trend in data: intercept (no trend) in CE. No intercept in VAR) is applied to this Greece time series data. The cointegration test results obtained from the Trace test and the Maximum Eigenvalue test are as follows:

Table 2: Johansen cointegration test

\begin{tabular}{|c|c|c|c|c|}
\hline Hypothesized Number of cointegration eq. & Eigenvalue & Trace statistic & $\begin{array}{c}\text { Critical value } \\
(5 \%)\end{array}$ & P-value \\
\hline none* & .771463 & 229.7774 & 134.6780 & $<.0000^{* *}$ \\
At most 1* & .389963 & 116.1211 & 103.8473 & $<.0000^{* *}$ \\
At most 2* & .276801 & 78.06501 & 76.97277 & $.0412^{*}$ \\
At most 3* & .219791 & 53.06501 & 54.07904 & .0609 \\
At most 4 & .206146 & 34.00070 & 35.19275 & .0668 \\
At most 5 & .131283 & 16.22480 & 20.26184 & .1641 \\
\hline
\end{tabular}

** highly significant, ${ }^{*}$ significant

Examining the trace test, at $r=0, r=1$, and $r=2$, we reject the null hypothesis of 'no cointegration' at the significance level of $5 \%$, but we cannot reject the null hypothesis that three cointegrated relation exist (see Table 2 ). In addition, there were some differences that the maximum eigenvalue test accepts at $r=0$, and rejects the null hypothesis at $r=1$ a null hypothesis unlike the trace test. Therefore, since all the integrals exist for time series data in Greece, the vector error correction model is analyzed instead of the vector autoregression model.

\subsection{Granger's causality test}

The vector error correction model needs to derive causal relationship between variables because the results of analysis differ differently according to the sequence of endogenous variables (Granger, 1969; Granger, 1980). In this case, the Granger causality test helps to predict between variables.

The choice of the time difference was based on the time when the Schwarz Criterion (SC) or HQ was the smallest value ' -10.11443 ' at lag ' 1 ' in the VAR model. Table 3 shows the results of testing Granger causality for seven variables in Greece.In the case of the housing price index, the real interest rate, the amount of money, stock index and household loans are considered to be the main variables, and current account seems to indirectly affect housing index through intermediary function among other variables. The stock index has a low impact on real interest rates and other variables, such as gross domestic product, household loans, monetary volume, and the housing price index.

Also, the effect of the asset was proved by the fact that the stock index and the housing price index influenced each other, and that the rise in the asset market price (the rise in the stock index and the housing market index) affected the current account.

In the case of Greece, foreign capital, which cheered Greece's participation in the launch of the euro, first flocked to the liquidity stock market, and the housing market overheated later. 
Table 3: Results of Granger causality test

\begin{tabular}{|c|c|c|c|c|c|}
\hline \multicolumn{2}{|c|}{ A does not cause B } & P-value & \multicolumn{2}{|c|}{ A does not cause B } & $\mathrm{P}$-value \\
\hline IR_REAL & $\begin{array}{l}\text { GDP } \\
\text { LOAN } \\
\text { M3 } \\
\text { HOUSING } \\
\text { STOCK } \\
\text { BCA }\end{array}$ & $\begin{array}{l}<.0001 * * \\
<.0001 * * \\
.0083 * * \\
.0001 * * \\
.0801 \\
.0022 * *\end{array}$ & M3 & $\begin{array}{l}\text { IR_REAL } \\
\text { GDP } \\
\text { LOAN } \\
\text { HOUSING } \\
\text { STOCK } \\
\text { BCA }\end{array}$ & $\begin{array}{l}.9455 \\
<.0001 * * \\
.0050 * * \\
.0037 * * \\
.0071 * * \\
.0035 * *\end{array}$ \\
\hline GDP & $\begin{array}{l}\text { IR_REAL } \\
\text { LOAN } \\
\text { M3 } \\
\text { HOUSING } \\
\text { STOCK } \\
\text { BCA } \\
\end{array}$ & $\begin{array}{l}.7373 \\
<.0001 * * \\
.0022 * * \\
.2715 \\
.0336 * \\
.0013 * * \\
\end{array}$ & HOUSING & $\begin{array}{l}\text { IR_REAL } \\
\text { GDP } \\
\text { LOAN } \\
\text { M3 } \\
\text { STOCK } \\
\text { BCA } \\
\end{array}$ & $\begin{array}{l}.4697 \\
.0128 * \\
<.0001 * * \\
.0013 * * \\
.0300 * \\
.0002 * * \\
\end{array}$ \\
\hline LOAN & $\begin{array}{l}\text { IR_REAL } \\
\text { GDP } \\
\text { M3 } \\
\text { HOUSING } \\
\text { STOCK } \\
\text { BCA } \\
\end{array}$ & $\begin{array}{l}.9974 \\
<.0001 * * \\
.0848 \\
<.0001 * * \\
.0087 * * \\
.2317 \\
\end{array}$ & STOCK & $\begin{array}{l}\text { IR_REAL } \\
\text { GDP } \\
\text { LOAN } \\
\text { M3 } \\
\text { HOUSING } \\
\text { BCA } \\
\end{array}$ & $\begin{array}{l}.3765 \\
<.0001 * * \\
<.0001 * * \\
.0002 * * \\
<.0001 * * \\
.0021 * * \\
\end{array}$ \\
\hline $\mathrm{BCA}$ & $\begin{array}{l}\text { IR_REAL } \\
\text { GDP } \\
\text { LOAN }\end{array}$ & $\begin{array}{l}.6920 \\
.3060 \\
<.0001 * *\end{array}$ & $\mathrm{BCA}$ & $\begin{array}{l}\text { M3 } \\
\text { HOUSING } \\
\text { STOCK }\end{array}$ & $\begin{array}{l}.7677 \\
.0602 \\
.0640\end{array}$ \\
\hline
\end{tabular}

** highly significant, * significant

\subsection{Results of vector error correction model}

When an error occurs from the long-term equilibrium relationship, the system tends to correct the error and recover this relationship. The model for expressing this error correction is the vector error correction model (Cho, 2006).

As a result of cointegration test in section 3.4, we found that there is a cointegration relationship between variables. Therefore, it is possible to analyze the vector error correction model using the variables under consideration (Sims, 1980). As shown in the Johansen cointegration test, let's apply Model 2 of the cointegration test in EViews 11.0.

\subsubsection{Estimation of vector error correction model and tests of significance}

As a result of estimation of the model given in Table 4, the goodness-of-fit of model $\left(\mathrm{R}^{2}\right)$ is generally higher than $50 \%$ for most variables except real interest rate (39\%). In addition, since all of the F-values, the significance test statistics for each variable, are significant, it can be judged as a meaningful estimation result.

Table 4: Estimation of vector error correction model

\begin{tabular}{|c|c|c|c|c|c|c|c|}
\hline & $\mathrm{D}(\mathrm{BCA})$ & D(IR_REAL) & $\mathrm{D}(\mathrm{GDP})$ & D(HOUSING) & $\mathrm{D}(\mathrm{LOAN})$ & D(M3) & D(STOCK) \\
\hline $\mathrm{D}(\mathrm{BCA}(-1))$ & $\begin{array}{l}1.103 \\
(7.05)\end{array}$ & $\begin{array}{c}0.0547 \\
(1.06)\end{array}$ & $\begin{array}{l}0.0007 \\
(-1.78)\end{array}$ & $\begin{array}{c}0.0014 \\
(1.08)\end{array}$ & $\begin{array}{c}-0.0006 \\
(-1.27)\end{array}$ & $\begin{array}{l}0.0018 \\
(1.26)\end{array}$ & $\begin{array}{c}-0.012 \\
(-1.9211)\end{array}$ \\
\hline $\mathrm{D}(\mathrm{BCA}(-2))$ & $\begin{array}{l}0.412 \\
(3.63)\end{array}$ & $\begin{array}{l}0.068 \\
(1.80)\end{array}$ & $\begin{array}{l}0.0004 \\
(0.93)\end{array}$ & $\begin{array}{l}0.0047 \\
(0.51)\end{array}$ & $\begin{array}{l}-0.0002 \\
(-0.72)\end{array}$ & $\begin{array}{l}0.0005 \\
(0.50)\end{array}$ & $\begin{array}{l}-0.0085 \\
(-1.91)\end{array}$ \\
\hline D(IR_REAL $\quad(-1))$ & $\begin{array}{l}0.534 \\
(1.30)\end{array}$ & $\begin{array}{l}-0.155 \\
(-1.14) \\
\end{array}$ & $\begin{array}{l}0.0025 \\
(1.69) \\
\end{array}$ & $\begin{array}{l}-0.003 \\
(0.84) \\
\end{array}$ & $\begin{array}{l}4.8 \mathrm{E}-5 \\
(0.04) \\
\end{array}$ & $\begin{array}{l}0.0012 \\
(0.34)\end{array}$ & $\begin{array}{l}0.005 \\
(0.33) \\
\end{array}$ \\
\hline D(IR_REAL (-2)) & $\begin{array}{l}0.261 \\
(0.71) \\
\end{array}$ & $\begin{array}{l}0.0252 \\
(0.21) \\
\end{array}$ & $\begin{array}{c}.0 .0001 \\
(0.09) \\
\end{array}$ & $\begin{array}{l}-0.002 \\
(-0.69) \\
\end{array}$ & $\begin{array}{l}0.0003 \\
(0.25) \\
\end{array}$ & $\begin{array}{l}0.0005 \\
(0.16) \\
\end{array}$ & $\begin{array}{l}-0.006 \\
(-0.45) \\
\end{array}$ \\
\hline $\mathrm{D}(\mathrm{GDP}(-1))$ & 46.670 & -24.212 & -0.040 & 0.177 & 0.051 & 0.415 & 3.604 \\
\hline
\end{tabular}




\begin{tabular}{|c|c|c|c|c|c|c|c|}
\hline & $(1.39)$ & $(-2.18)$ & $(-0.32)$ & $(0.65)$ & $(0.51)$ & $(1.39)$ & $(1.32)$ \\
\hline \multirow{2}{*}{$\mathrm{D}($ GDP(-2)) } & -26.70 & 2.480 & 0.272 & 0.069 & -0.073 & 0.051 & 0.690 \\
& $(-0.73)$ & $(0.20)$ & $(1.99)$ & $(0.23)$ & $(-0.68)$ & $(0.16)$ & $(0.48)$ \\
\hline \multirow{2}{*}{$\mathrm{D}$ (HOUSING(-1) } & 39.124 & -1.333 & 0.025 & -0.179 & 0.165 & 0.149 & 0.811 \\
& $(2.58)$ & $(-0.26)$ & $(0.45)$ & $(-1.45)$ & $(3.70)$ & $(1.10)$ & $(1.35)$ \\
\hline \multirow{2}{*}{$\mathrm{D}$ (HOUSING(-2) } & -1.652 & 0.221 & -0.044 & 0.087 & -0.040 & -0.072 & -0.101 \\
& $(-0.10)$ & $(0.04)$ & $(-0.72)$ & $(0.66)$ & $(-0.84)$ & $(-0.05)$ & $(-0.16)$ \\
\hline \multirow{2}{*}{$\mathrm{D}($ LOAN(-1)) } & 74.944 & -2.407 & 0.009 & -0.160 & 0.821 & 0.466 & 0.641 \\
& $(1.71)$ & $(-0.17)$ & $(0.05)$ & $(-0.45)$ & $(6.36)$ & $(1.19)$ & $(0.37)$ \\
\hline \multirow{2}{*}{$\mathrm{D}($ LOAN(-2)) } & 28.230 & -35.133 & 0.169 & 0.769 & -0.082 & -0.964 & 0.331 \\
& $(0.64)$ & $(-2.41)$ & $(1.03)$ & $(2.15)$ & $(-0.63)$ & $(-2.46)$ & $(0.19)$ \\
\hline \multirow{2}{*}{$\mathrm{D}(\mathrm{M} 3(-1))$} & -0.635 & -1.386 & -0.045 & -0.015 & 0.036 & 0.322 & 0.240 \\
& $(-0.04)$ & $(-0.30)$ & $(-0.85)$ & $(-0.13)$ & $(0.87)$ & $(2.55)$ & $(0.43)$ \\
\hline \multirow{2}{*}{$\mathrm{D}(\mathrm{M} 3(-2))$} & -38.71 & 5.781 & 0.038 & 0.115 & -0.076 & 0.101 & 0.167 \\
& $(-2.83)$ & $(1.28)$ & $(0.76)$ & $(1.03)$ & $(-1.88)$ & $(0.82)$ & $(0.31)$ \\
\hline \multirow{2}{*}{$\mathrm{D}(\mathrm{STOCK}(-1))$} & 10.266 & 0.664 & 0.005 & 0.033 & -0.001 & -0.013 & 0.316 \\
& $(3.15)$ & $(0.62)$ & $(0.38)$ & $(1.23)$ & $(-0.14)$ & $(-0.46)$ & $(2.47)$ \\
\hline \multirow{2}{*}{$\mathrm{D}(\mathrm{STOCK}(-2))$} & $(7.795)$ & 1.833 & -0.028 & -0.004 & 0.004 & 0.036 & -0.163 \\
& $(2.45)$ & $(1.74)$ & $(-2.40)$ & $(-0.14)$ & $(0.45)$ & $(1.27)$ & $(-1.30)$ \\
\hline \multirow{2}{*}{$\mathrm{R}^{2}$} & 0.813 & 0.393 & 0.630 & 0.514 & 0.943 & 0.520 & 0.422 \\
\hline F-statistic & 16.374 & 2.431 & 6.389 & 3.971 & 6.2104 & 4.058 & 2.748 \\
\hline
\end{tabular}

+ Note that () is the calculated t-test statistic

As a result of testing the parameters included in the model, the current account is heavily influenced by its own variables, stock index, housing price index and currency volume, Real interest rate by gross domestic product and household loans, gross domestic product by its own variables and stock index, home price index by household loans, household loans by its own variables and house price index, currency volume by its own variables and household loans, and the stock index by its own variables, gross domestic product and current account, respectively.

\subsubsection{Results of impulse response function}

Impulse response function describes how the variables in the model react when a single shock occurs as shown in Figure 1 (Hatemi-J, 2014). Current account balances are affected by alternating signs in their own variables or stock indexes, and increase over time as a negative relationship to GDP. While real interest rates continue to be positively affected by their own variables, they have a strong negative response to household loans over time. The current account and home price index are smaller than household loans in degree, but have a negative effect on real interest rates.

In the case of gross domestic product, over time, its own variables continue to rise, while the current account, household loans, and stock indexes show strong positive responses. On the other hand, negative rates gradually increase in real interest rates and in the volume of money.

In the case of the housing price index, there is a constant positive effect on its own variables, and there are strong positive responses on the current account balance, gross domestic product, household loans, and stock indexes over time.

In the case of household loans, it shows the strongest positive response to its own variables over time, and a relatively weak positive response to the current account, household housing index and stock index. On the other hand, it appears negative response to real rates and currency.

In the case of monetary volume, there is a strong positive response to its own variables, and a strong positive response to the current account and GDP over time, and negative for real interest rates and household loans.

Finally, in the case of the stock index, there is a strong positive response to all the variables compared to other dependent variables, and it shows consistently strong positive effect on its own variables, the current account and the GDP. 

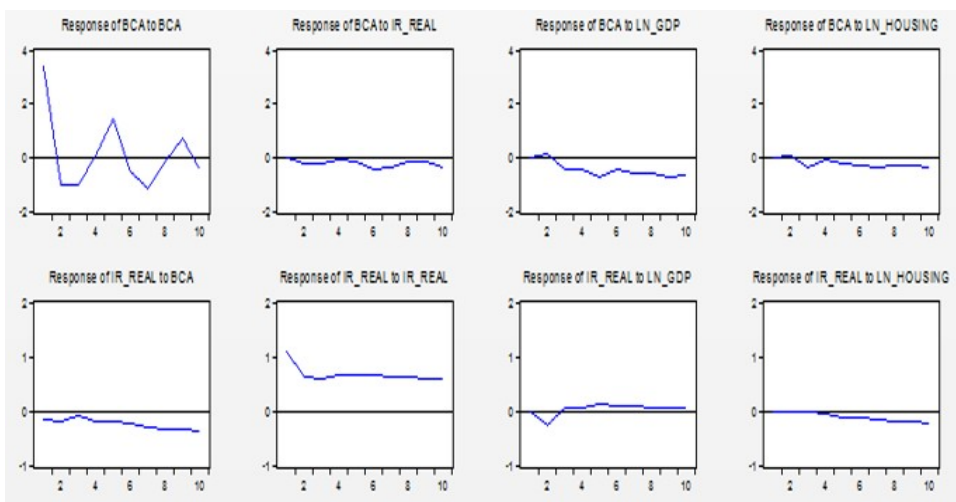

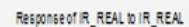

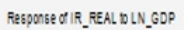

Regponse Q 1 R_REAL W L H HOUSNG
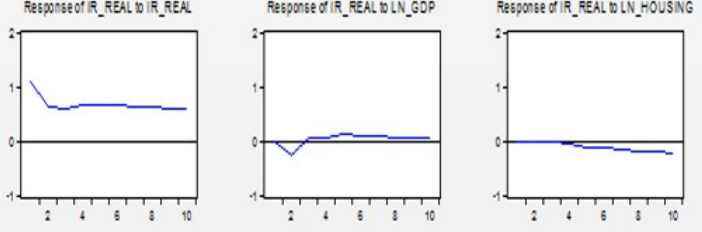

Regponse of LN_ GDP 10BCA
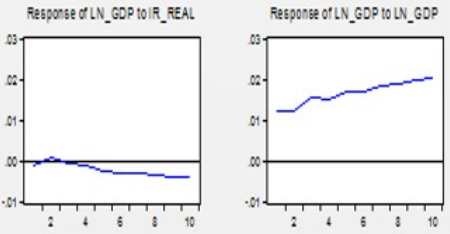

Regponse or LN_GDP TO LN_HOUSNG

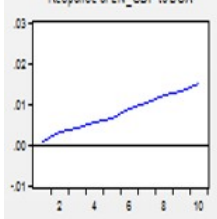

Regonse o d L _ HOUSNG 10BCA

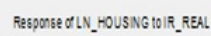
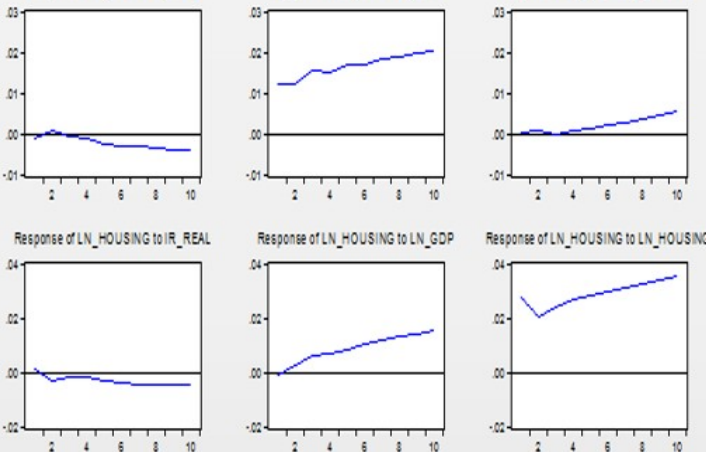

Response or LN_HOUS ING I0 LN_HOUSNG

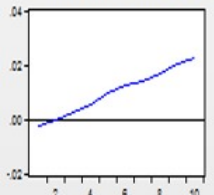

Figure 1-1: Results of impulse response function
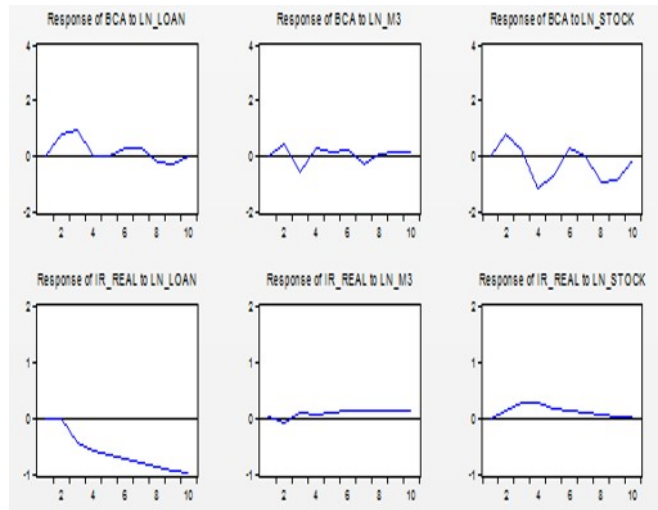

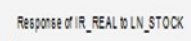

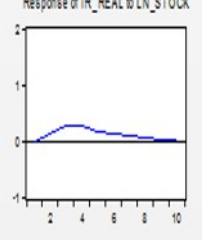

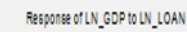
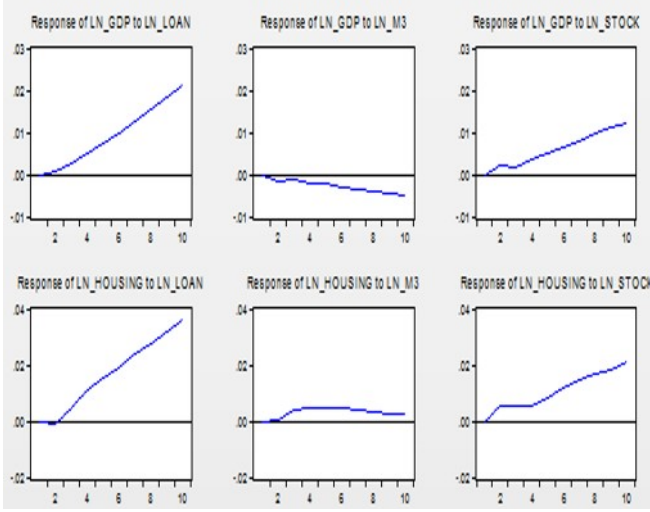

Figure 1-2: Results of impulse response function (to be continued) 


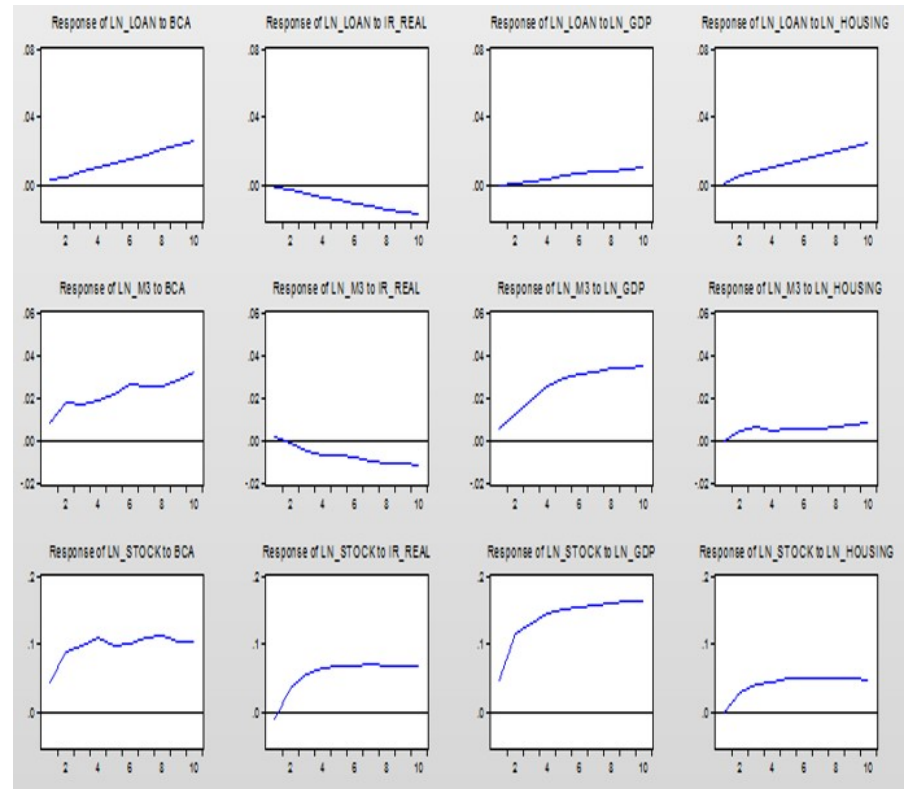

Figure 1-3: Results of impulse response function (to be continued)

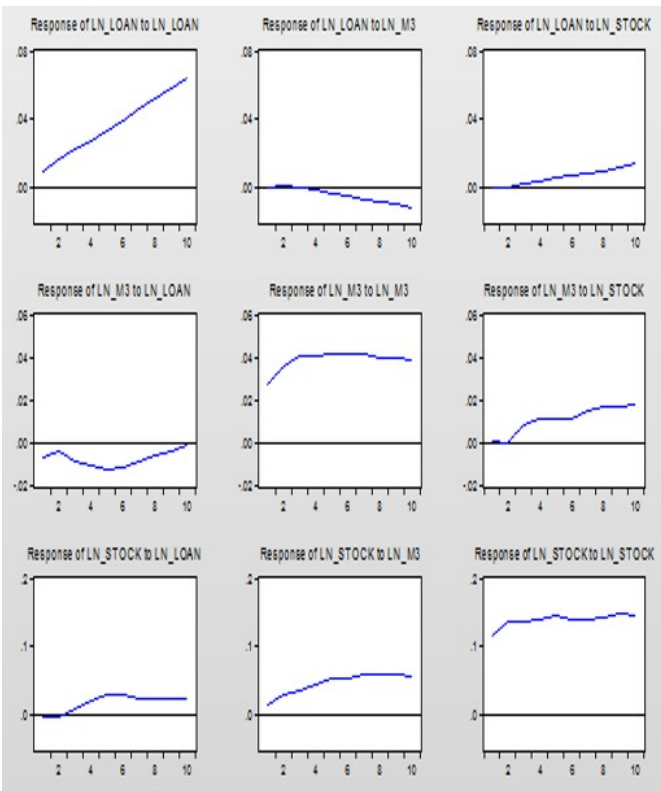

Figure 1-4: Results of impulse response function (to be continued)

\subsubsection{Results of variance decomposition}

Variance decomposition is an analysis method that can determine the relative importance of each variable in the model, and the results of variance decomposition between seven variables are shown in Figure 2 (Lütkepohl, 2007).

As a result of variance decomposition of the forecasting error of the current account, the explanatory power of self-variables decreases with time, but the explanatory power exceeds $60 \%$. The explanatory power of stock index and gross domestic product has increased to some extent in the end $(15.14 \%, 9.92 \%$, respectively).

Real interest rates account for nearly $90 \%$ of their variables and household loans, and the explanatory power of real interest rates continues to decline over time, while household loans increase to $44.2 \%$. 
In the case of gross explanatory power, self-explanatory power initially occupied nearly $100 \%$, but over time, the explanatory power decreased to $48.39 \%$. On the other hand, household loans and current account accounted for a steady increase from less than $3 \%$ initially, accounting for $23.5 \%$ and $14.2 \%$, respectively.

The explanatory power of the housing price index, like other variables, initially accounted for nearly $100 \%$, but eventually decreased to $48.9 \%$ over time, and household loans increased steadily by $25.2 \%$ at the end. In addition, the stock index and the current account also increased explanatory power, showing $9 \%$ and $10 \%$ respectively.

Compared to the Granger's test, household loans were identified as equally explanatory variables, but the impact of real interest rates and the volume of money was not confirmed.

In the case of explanatory power of household loans, self-explanatory power continued to occupy most of them from the beginning (about $70 \%$ ), and the current account balance and the housing price index gradually increased to account for $10.7 \%$ and $9.8 \%$, respectively.

The explanatory power of the monetary amount also continued to decrease, with self-explanatory power initially accounting for the most, with a final $48.4 \%$ explanatory power, and Gross domestic product and current account continue to increase, accounting for the final $24.2 \%$ and $17.1 \%$ explanatory power.

Finally, in the case of the explanatory power of the stock index, self-explanatory power gradually decreased, accounting for about $33.3 \%$, while gross domestic product and current account increased steadily, with the final $35.5 \%$ and $16.8 \%$ explanatory power. Gross domestic product, which was identified as a major factor in the Granger's test, was reaffirmed as a variable with high explanatory power

On the other hand, the variables most affected by the two asset markets can explain about $10 \%$ of household loan fluctuations and about $3 \%$ of stock index fluctuations due to the housing index.

From the stock index, there was an impact on about $15 \%$ of the current account balance, $9 \%$ of the housing index, and $9 \%$ of gross domestic product. In other words, the mutual impact between asset markets was reaffirmed.

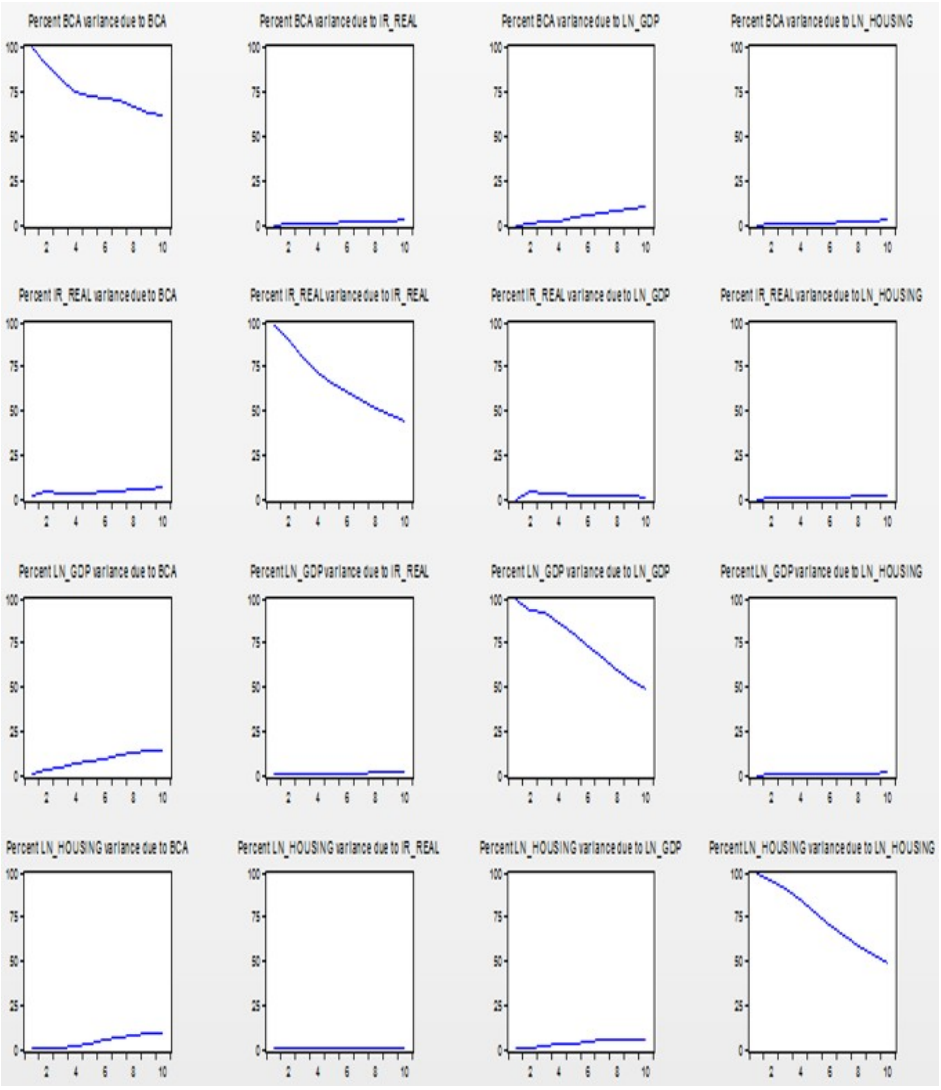

Figure 2-1: Results of variance decomposition 

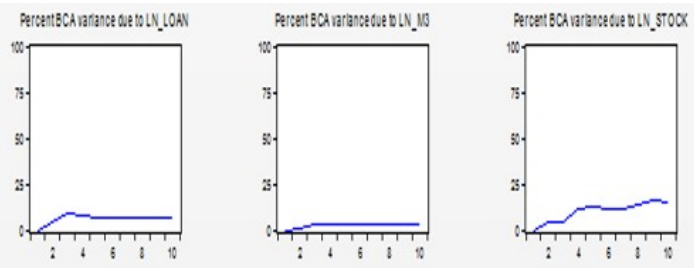

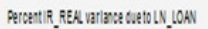

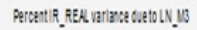

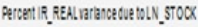
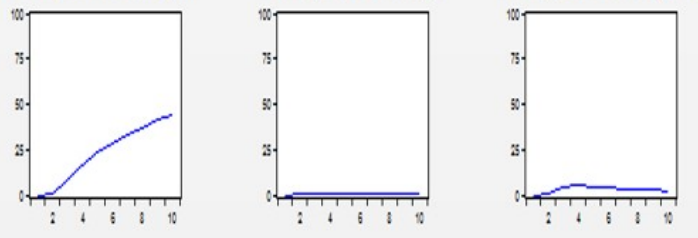

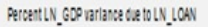

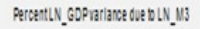

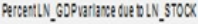
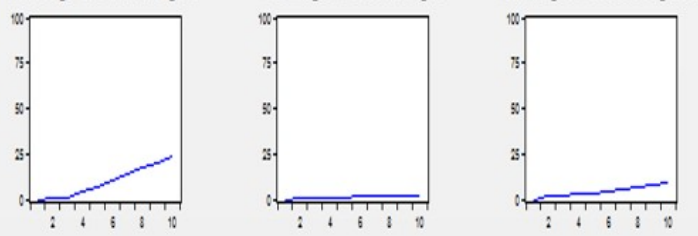

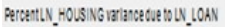

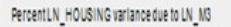

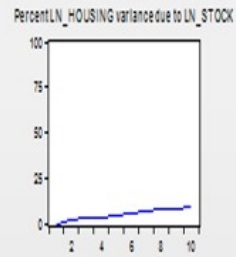

Figure 2-2: Results of variance decomposition (to be continued)
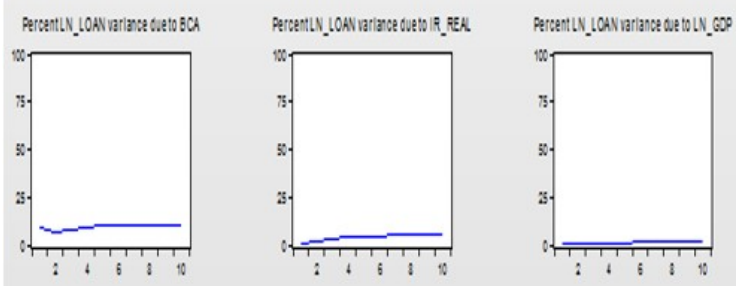

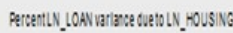

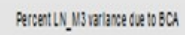

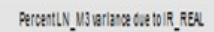

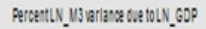
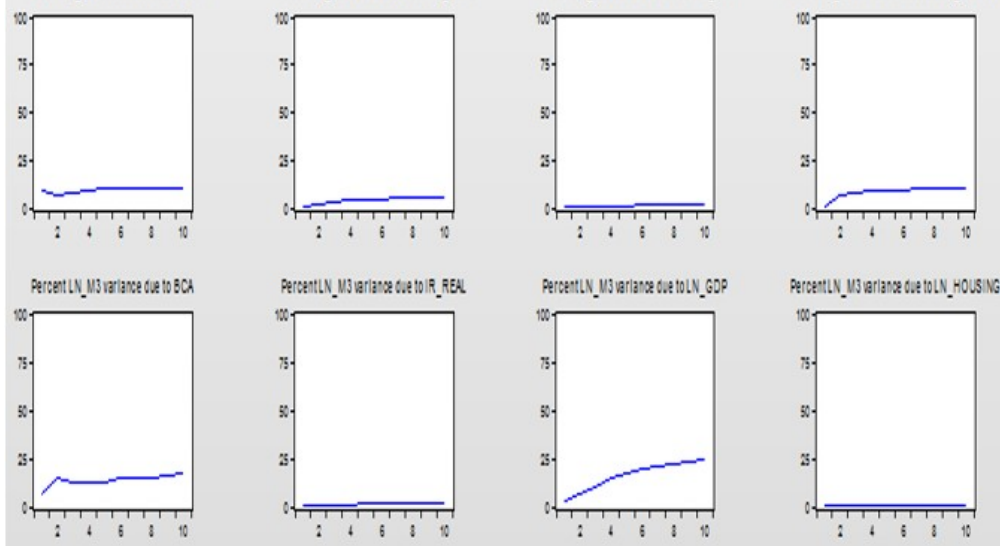

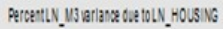
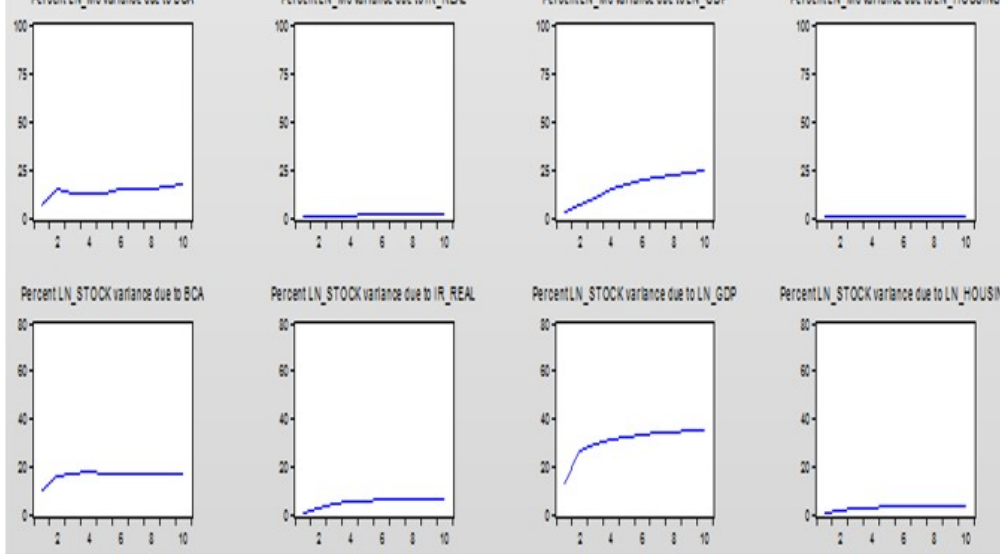

Figure 2-3: Results of variance decomposition (to be continued) 


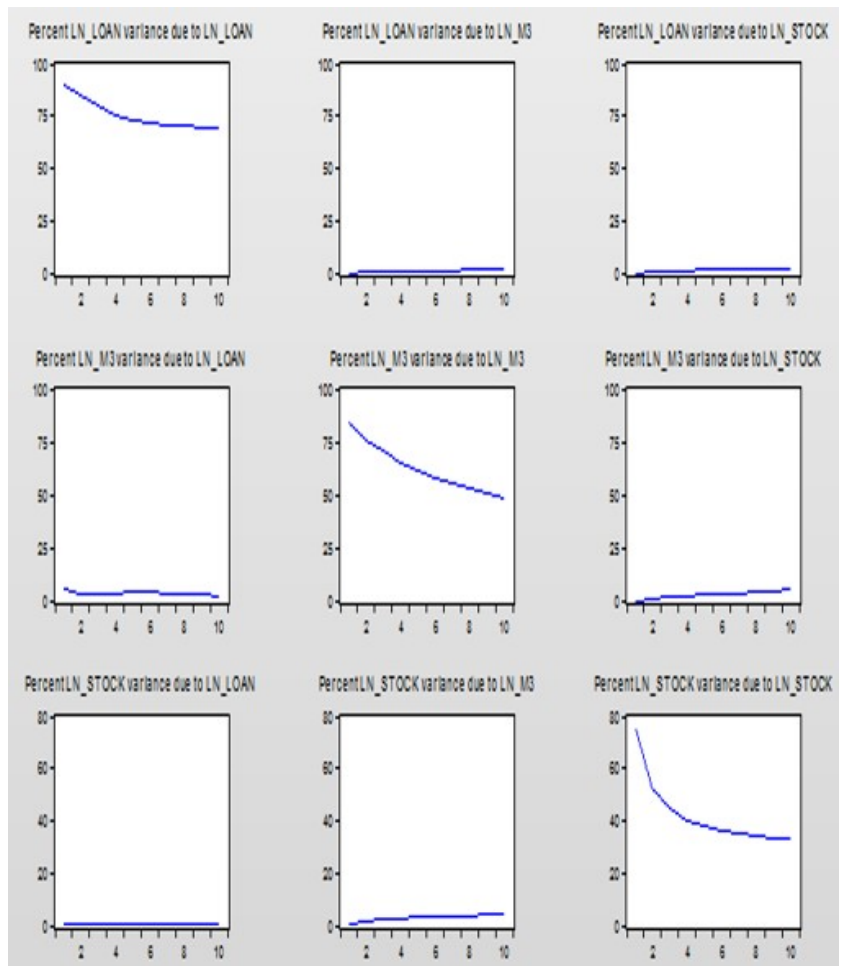

Figure 2-4: Results of variance decomposition (to be continued)

\section{Concluding remarks, limitation and future study}

This study examines what are the asset market fluctuations in Europe and how each economic variable affects major variables through Greece, which represents the European financial crisis. To investigate this, the relationship between the current economic balance, real interest rate, gross domestic product, housing price index, household loans, monetary volume, and stock index, which are the main economic variables of Greece, were analyzed using various statistical techniques.

The key variables, causality and response to asset market volatility are summarized below.

First, as a result of analyzing the ADF test to check the stationarity of time series data, it was found that all the economic variables considered were nonstationary time series with a unit root.

Second, the Johansen cointegration test determines if the cointegration exists or not. According to these results, it is expected that there will be a long-term equilibrium relationship between the seven variables.

Third, the stock market was influenced by gross domestic product, household loans, currency volume and the housing price index, but unlike the United States, the housing market was largely unaffected by gross domestic product and the explanatory power of household loans was overwhelming through Granger's causality test. In this regard, it can be judged that the policy that affects the lending policy of financial institutions may be more effective than the indirect variable such as monetary interest rate.

The housing index fluctuates, with leading to stock indices, household loans, real interest rates, and monetary volume rather than the gross domestic product, which suggests that there was speculative demand for housing. Judging the cross-market impact, the stock market has a one-sided effect on the housing market, as shown by the Granger analysis. This confirms the fact that Greece's stock index surged before and after joining the Euro-zone, and the heat spread to the housing market.

Forth, it was found that three cointegrations exist between variables and analyzed by vector error correction model. Overall, several variables appear to be mutually influencing and forming long-term equilibrium relationships, and stock indexes and household debt are highly dependent on their own variables. While the housing market is significantly affected by household loans, the stock market is affected by gross domestic product and current account. 
Fifth, impulse response function and variance decomposition showed that the stock market had a significant impact on the housing market. Household loans were the main variable explaining the changes in the housing market, and gross domestic product and current account deficits were interpreted as variables explaining the changes in the stock market.

Since the stock market price was the main cause of the current account deficit, and the housing market was the main factor of household loan, not managing two variables and sticking to monetary policy such as monetary interest rates could not be a good policy. It is possible to control the bubble in the asset market by managing the current account and household loans. On the other hand, as a policy measure, it was concluded that currency management would be difficult to intervene in the asset market through variance decomposition.

In the 21 st century crisis economics, which diagnoses crisis occurrences to prevent future crisis occurrences or to present countermeasures, we should find out the economic situation that should be used as a sign of crisis in common to all countries rather than the independent exogenous factors of crisis and make it a task to improve it.

As a limitation of the study, it is difficult to generalize the conclusion considering Greece only as a representative country of the European economic situation. It would be worthwhile to expand this and consider the econometric model comprehensively, including major European countries.

Forecasting future markets is not easy, but overall European real estate market and housing price growth will slow. However, this does not mean a market crash, and it is not a trend over the years that have been profitable in the short term through residential assets.

\section{References}

Bae, B.I. (2016). European fiscal crisis and economic integration: evolution of and the challenges to the European union. Journal of Contemporary European Studies, 34(4), 393-415.

Cho, D. (2006). Introductory Financial Econometrics. Seoul, Korea: Cheongram Academy.

Dickey, D.A. \& Fuller, W.A. (1979). Distribution of the estimators for autoregressive time series with a unit root. Journal of the American Statistical Association, 74(1), 427-431.

Engle, R.F. \& Granger, C.W.J. (1987). Co-integration and error correction: representation, estimation and testing. Econometrica, 55(2), 251-276.

Gourinchas. P. O., \& Obsfeld, M. (2012). Stories of the twentieth century for the twenty-first. American Economic Journal: Macroeconomics. 4(1), 226-265.

Granger, C. W. J. (1969). Investigating causal relations by econometric models and cross-spectral methods. Econometrica, 37(3), 424-438.

Granger, C.W.J. (1980). Testing for causality: a personal viewpoint. Journal of Economic Dynamics and Control, 2(1), 329-352.

Granger, C.W. J. (2004). Time series analysis, cointegration, and applications. American Economic Review, 94(3), $421-425$.

Hatemi-J, A. (2014). Asymmetric generalized impulse responses with an application in finance. Economic Modelling, 36(1), 18-22.

Koo, C. K. (2015). Formation of Euro capitalism and restructuring of German model. Korean and World Politics, $32(4), 107-145$.

Lütkepohl, H. (2007). New Introduction to Multiple Time Series Analysis. Berlin: Springer-Verlag.

Park, H. M. \& Yi, C. D. (2014). A VECM analysis of monetary and fiscal policies for the EU. Journal of Contemporary European Studies, 32(1), 331-372.

Reinhart, C. M., \& Rogoff, K. S. R. (2009). The aftermath of financial crises. American Economic Review, 99(2), 466-472.

Said, S. E. \& Dickey, D. A. (1984). Testing for Unit Roots in Autoregressive-Moving Average Models of Unknown Order. Biometrika, 71(3), 599-607.

Schularick, M., \& Taylor, A. M. (2012). Credit booms gone bust: monetary policy, leverage cycles, and financial crises, 1870-2008. American Economic Review, 102(2), 1029-61.

Sims, C. A. (1980). Macroeconomics and reality. Econometrica, 48(1), 1-48. 